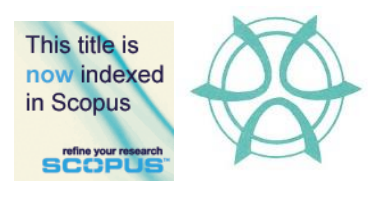

PLANNING MALAYSIA:

Journal of the Malaysian Institute of Planners

VOLUME 17 ISSUE 1 (2019), Page 104 - 115

\title{
ONE STOP CENTRE (OSC): LESSONS ON BEST PRACTICES IN PLANNING SYSTEM DELIVERY
}

\author{
Marlyana Azyyati Marzukhi ${ }^{1}$, Dasimah Omar $^{2}$, Ahmad Fuzi Arshad ${ }^{3}$, \\ Oliver Ling Hoon Leh ${ }^{4}$, Mohammad Yusup ${ }^{5}$, \& Azfarnizam Jaafar ${ }^{6}$ \\ 1,2,3,4,5 Faculty of Architecture, Planning and Surveying \\ UNIVERSITI TEKNOLOGI MARA, MALAYSIA
}

${ }^{6}$ SUBANG JAYA MUNICIPAL COUNCIL

\begin{abstract}
Malaysia has been experiencing rapid development since its independence in 1957, which has transformed its economic base from agriculture to industry. Rapid urbanisation has, itself, led to the continued rise of economic growth, and an acceleration of neoliberal market values. In turn, these have (re)shaped Malaysia's planning system. Certainly, planning systems have a role in contributing, often directly, to the country's needs and aspirations, particularly in the decision-making process. This effort is evidenced by the improvement of the planning system's delivery mechanism, known as One Stop Centre (OSC). The OSC was initiated by the Ministry of Urban Wellbeing, Housing and Local Government on the $13^{\text {th }}$ of April, 2007 to improve the planning system delivery and procedures at all local planning authorities by coordinating and shortening the approval process. However, relatively little is known about the effectiveness of OSC in the property development sector. Hence, this paper presents a synthesis of results on the effectiveness of OSC in other countries, with the objective of developing an understanding of how OSC rationalizes the success of the property development sector through its policies and planning practices. The knowledge of these theoretical situations serves as a basis for future strategic planning decisions, and as a guide in the planning system delivery of real estate development, particularly in the Malaysian context.
\end{abstract}

Keywords: decision-making, planning, delivery system, One Stop Centre, development 
PLANNING MALAYSIA

Journal of the Malaysia Institute of Planners (2019)

\section{INTRODUCTION}

By 2030, an estimated one in every three people from $60 \%$ of the world's population will live in cities with at least 1 million inhabitants (United Nations, n.d.). An understanding of this increasing urbanisation is critical as the physical form of the urban environment poses massive sustainability challenges. The Sustainable Development Goals have given new impetus to improve city development, as stated in Goal 16: to "develop effective, accountable, and transparent institutions at all levels," and to "ensure responsive, inclusive, participatory, and representative decision-making at all levels" (United Nations, n.d.). In this sense, the planning system delivery must be made even more efficient and effective to promote sustainable development, particularly by local authorities.

The success of a development project as a whole is crucial to all the stakeholders, who primarily are the developer, the land owner, and property buyer. The timely completion of a project that is not only within the budget, but also in accordance to specifications and the stakeholder's satisfaction, benefits both the project owner (developer), and the property buyer (Nguyen, Ogunlana, $\&$ Lan, 2004). Every project development will undergo some form of a project life cycle (PLC) (Kerzner, 2009). If procedures are too complicated or costly, developers tend to proceed with development without a permit (Moullier, 2009). In fact, it is estimated that $60 \%$ to $80 \%$ of building projects in developing economies are undertaken without proper permits and approvals (Hernando, 2000).

Furthermore, time and procedures are the biggest "regulatory impediments" to rationalizing the success of the property development sector. Time taken by authorities, especially for the issuance of design approval, is uncertain, and difficult to predict (Kincaid, 2003). Similarly, a case study carried out by Mitropoulos and Howell (2002) found that the main reason for the delay in development projects was the process of getting approval from local authorities. When delays occur, the overall cost for the project would also be affected. McKim, Tarek and Attala (2000) mentioned that one of the factors contributing to cost and schedule overruns is the regulatory requirements. In some cases, the plans and drawings had to be submitted more than once due to amendments that need to be complied with. This is sometimes due to the complexity of the requirements set by the respective authorities (ibid.).

Accordingly, the local authorities are also the local planning authorities for their administrative areas (Town and Country Planning Act 1976). The functions of local authorities are expanding to various roles, which include development planning and control, and particularly, planning system delivery (ibid.). As questioned by Rashid (2012): "How can local authorities become an effective machinery to facilitate national growth, and enhance the nation's competitive edge?" In this sense, it becomes important for the local authority to 
Marzukhi, M.A., Omar, D., Arshad, A.F., Oliver L.H.L.,, Yusup,M., \& Jaafar, A.

One Stop Centre (OSC): Lessons on Best Practices in Planning System Delivery

ensure an effective decision-making process, particularly in land development "for better improvement to generate and assist the property market institution" (Ahmad, Ahmad, \& Arbi, 2011).

The federal government of Malaysia understands the need to speed up and standardise design approval procedures; therefore, it has introduced the One Stop Centre framework on April 13, 2007, to help expedite approval of construction permits (PEMUDAH, 2010). It also provides local authorities in Malaysia the common design approval procedures for new development applications. This effort is evidenced by the improvement of the delivery mechanism, known as One Stop Centre (OSC).

\section{RESEARCH BACKGROUND}

The planning system in Malaysia adopts a 'top-down' approach, starting at the federal level, then at the state level, and finally at the local authority level (Abdullah, Harun, \& Rahman, 2011). There are three types of local authorities in Malaysia: the city council, the municipal council, and the district council. Accordingly, "the local authorities, or the government carries out obligatory, discretionary services, and are the agents of development, whose function is to provide services that are non-profit-making to the people, including various other mandatory services" (Maidin, 2012). In relation to town and country planning, the local authority functions as the local planning authority whose responsibility is to "regulate, control, and plan the development and use of all lands and buildings within its area" (section 6(1)(a), Town and Country Planning Act 1976). The local planning authority has the power to execute town and country planning functions as outlined in local plans (Omar \& Leh, 2009). More importantly, the local planning authority must play a more effective role to ensure sustainable development by managing the urban system, and its environment.

In essence, the OSC was initiated by the Ministry of Housing and Local Government (MHLG) in April 2007 to improve the planning system delivery and procedures at all local planning authorities by coordinating and shortening the approval process. The procedure includes applications for planning permission, building plan approval, land conversion, subdivision, and amalgamation (Ministry of Housing and Local Government, 2008). Significantly, the actual planning consent decision-making process in Malaysia is decided by the planning approval committee at the local authorities where the OSC is positioned.

Moreover, the purpose of the OSC is to improve the planning system in its delivery, and contribute towards property development in Malaysia. However, relatively little is known about the effectiveness of OSC in the property development sector. This is despite the fact that development in Malaysia is aimed at promoting economic development (Watson, 2013). In this sense, this paper presents a synthesis of results on the effectiveness of OSC in other countries, i.e. Singapore, and New Zealand, with the objective of developing an 
PLANNING MALAYSIA

Journal of the Malaysia Institute of Planners (2019)

understanding of how OSC rationalizes the success of the property development sector through its policies and planning practices.

\section{ONE STOP CENTRE}

The government, at the Cabinet Meeting on the 25th of February, 2004, approved a proposal by the MHLG to establish OSC in all local authorities in Peninsular Malaysia (Ahmad et al., 2011). The report on OSC performance, with the improvement of delivery procedures and processes, then obtained Cabinet approval in 2007 (Ministry of Housing and Local Government, 2008). Following this, all local authorities immediately set up an OSC to manage development proposals, covering planning permission applications, building plans, land conversions, subdivisions, and amalgamations, with the main objective being to shorten the duration for approvals in the planning process. In this regard, an OSC Committee was established and authorized to consider and decide upon applications for planning permissions, building plans, and land matters. In fact, the local authority is the main agency that is responsible to administer, plan, and manage urban development. With the establishment of the OSC, it is hoped that cases of duplication, or double-loading of technical reviews during the processing of planning permission applications, building plans, and applications for land development approvals can be avoided.

Moreover, the growth in construction activities in Malaysia since the 1980 's has given rise to the need for statutory controls to ensure systematic and orderly development. This process of statutory approval refers to the obtaining of permissions from the relevant authorities to initiate and construct a facility and, upon its completion, to occupy and use the completed facility. As mentioned earlier, the main functions of the OSC are to distribute and coordinate the applications for planning permission, building plan approval, and land matters (i.e. land conversions, subdivisions, and amalgamations). Therefore, the establishment of OSC is critical to shorten the approval process, and improve planning system delivery in Malaysia.

However, among the recorded 190 nations in the 2018 World Bank's annual report of Ease of Doing Business Ranking, Malaysia is currently at $24^{\text {th }}$ place (from $13^{\text {th }}$ spot in 2017) (The World Bank, 2018) whereas our neighbour, Singapore, takes a higher spot at $2^{\text {nd }}$ place. This shows that the Malaysian planning system delivery still needs a lot of improvement to compete with other nations, particularly New Zealand ( $1^{\text {st }}$ in World Bank rank), and Singapore ( $2^{\text {nd }}$ in World Bank rank). In this context, this article is vital to develop an understanding of how the delivery of the planning systems in Singapore and New Zealand rationalize the success of the property development sector through their policies and planning practices. The knowledge of these theoretical situations will serve as a basis for future guidance in the planning system delivery of real estate development in Malaysia. 
Marzukhi, M.A., Omar, D., Arshad, A.F., Oliver L.H.L.,, Yusup,M., \& Jaafar, A.

One Stop Centre (OSC): Lessons on Best Practices in Planning System Delivery

\title{
LESSONS ON BEST PRACTICES: SINGAPORE AND NEW ZEALAND
}

\begin{abstract}
Singapore
Singapore is located below the southern part of Peninsular Malaysia, and covers an area of about $719.9 \mathrm{~km}^{2}$ (Singapore Department of Statistics, 2017). It is home to a population of 5.61 million, with a population density of 7,797 per sq $\mathrm{km}$ in 2016 (ibid.). Singapore aims to optimise the use of the country's limited land area for the diverse needs of both current and future generations. Singapore gained its independence in 1965, and transformed its nation to a developed one in less than fifty years (Yuen, 2009). Singapore is known for its efficiency and success in managing its urban planning matters (http://global-is-asian.nus.edu.sg, 2017). The urban planning system in Singapore was formulated and legislated based on the Town and Country Planning Act 1947 in Britain, and the implementation of plans highly comply with development control and planning regulations (Yuen, 2009).
\end{abstract}

\section{The Planning Process and Practices}

Most of the development that involves construction, and change of use in Singapore requires planning permission. The land use planning is implemented according to, and complies with development control and planning regulations, which has gained international recognition as a model of good governance practice (Yuen, 2009). Control over land allocation and development is vital due to the limited land area, and the rising value of land in Singapore. The highest level of central decision-making in Singapore is the Cabinet, which was adopted from the British parliamentary system. On the other hand, the Urban Redevelopment Authority (URA) - a statutory board under the Ministry of National Development, is the national planning authority of Singapore that functions as a central planning agency to process planning and development control systems, enforcement of planning policies and standards, and development constraints.

The goal for Singapore's land use planning is "to create a sustainable Singapore that provides a quality living environment, offers plentiful growth opportunities and jobs for the people, and safeguards our clean and green landscape" by balancing economic, social, and environmental considerations (Urban Redevelopment Authority, n.d.). The development in Singapore is based on a long-term planning approach which is done in two segments: the Concept Plan (40 to 50 years' plan, reviewed every ten years), and the Master Plan (10 to 15 years' plan, reviewed every five years). The URA plays the role of preparing these long-term strategic plans, and bringing them to reality. The application for development control must refer to the Master Plan that shows all the permissible land use and density for developments which need to be read with the planning 
PLANNING MALAYSIA

Journal of the Malaysia Institute of Planners (2019)

legislation, i.e. The Planning Act Master Plan Written Statement 2014 (last revised on 15 January 2016).

The URA regulates and controls developments to ensure that the planning system delivery follows the statutory Master Plan, which includes land use, building height, and plot ratio. Here, the Concept Plan and Master Plan are of significance as they have been used to endorse the various planning applications. The Development Control department will evaluate the applications for planning permission/development work before granting approval to ensure the development will be in line with Singapore's planning strategies and guidelines. Moreover, to ensure the development is integrated well with the citizens' environmental, social, and economic wellbeing, the department holds frequent dialogues and discussions with professional bodies, and the public. According to the Planning Act, "development" means the carrying out of any building, engineering, mining, earthworks, or other operations in, on, over, or under land, or the making of any material change in the use of any building or land, and the terms "develop" and "developing" shall be construed accordingly. As such, unless specifically exempted, all development works in Singapore require planning permission approval from the URA.

The planning system delivery in Singapore is conducted via electronic submission, or also known as 'CORENET' (Construction and Real Estate Network e-Submission System). The CORENET is used to register and submit a development application for planning permission, and other applications to other relevant authorities. The development control submission checklist (submission and planning requirements) are also available in the system to serve as a guide for the Qualified Person (QP). Accordingly, the URA has produced a series of handbooks on development control, such as Development Control Parameters for Residential Development, Development Control Parameters for Non-Residential Development, and Conservation Guidelines. The Qualified Person (QP), one who can submit a development application, can check the status within 20 working days after the submission date. However, with complex cases, more time may be required to evaluate the application.

\section{New Zealand}

New Zealand is located in the Southwestern Pacific ocean, and geographically comprises two landmasses - North Island, and South Island. The total area covers about 268,021 km² (StatsNZ, n.d.). The population in New Zealand is estimated at 4.7 million, based on the 2013 census (ibid). In fact, New Zealand's population has the fastest growth rate in the past few years, with a $2.1 \%$ population growth in 2016 (Fyers \& Flahive, 2017). 
Marzukhi, M.A., Omar, D., Arshad, A.F., Oliver L.H.L.,, Yusup,M., \& Jaafar, A

One Stop Centre (OSC): Lessons on Best Practices in Planning System Delivery

\section{The Planning Process and Practices}

In New Zealand, the application for planning permission is known as an application for resource consent, or submission of an application or council planning document (Ministry for the Environment NZ, n.d.). The Resource Management Act 1991 (RMA) is New Zealand's main legislation that outlines the processes of resource consents, council plans and designations, proposals of national significance, and the types of legislative tools issued under the RMA, among others.

According to the RMA, local authorities have to prepare plans to manage the physical environment in the local authorities' area. The plans include Regional policy statements that set the basic direction for environmental management in the region, Regional plans that concentrate on practical parts of the environment such as coasts, soil, rivers, or air, and District plans that set out the objectives, policies, and rules of local authorities in managing the use and development of the land in their area (Ministry for the Environment NZ, n.d.). For example, the Auckland Plan is used to guide Auckland's future (30 years' plan) in solving issues such as reducing transport and housing shortages, and protecting the environment, whereas the Unitary Plan is used to help Auckland meet its economic and housing needs, particularly by determining what can be built and where in the local authorities' areas.

The planning system delivery in New Zealand is conducted based on three main stages that give resource consents permission to use or develop a natural or physical resource, and carry out an activity that affects the environment. Accordingly, an application for a resource consent is made to the local authorities. In certain circumstances, resource consent applications for nationally significant projects are decided on by a board of inquiry, or the Environment Court instead of the local authorities. This process is almost similar to the Malaysian planning context, in which specific developments, as outlined under section 22(2A), shall request from the National Physical Planning Council its advice on the application submitted. The three main stages of the resource consent process are as follows:

\section{Stage One: The applicants prepare their application}

The applicant, or a resource management planning consultant, prepares an application for proposed development. Before applicants submit their application for resource consent, they may consult local authorities for written approval. The local authorities will inform the applicants what information they need to provide, how long the process of resource consent is likely to take, and the costs that will be incurred. During this stage, the local authorities will advise the applicants on making any changes to remove or reduce any adverse effects of the project development. 
PLANNING MALAYSIA

Journal of the Malaysia Institute of Planners (2019)

The applicants need to complete and submit an application form together with an assessment of environmental effects (AEE). The AEE is essential to describe all the environmental impacts of the proposed development, and the mitigation measures if the development causes any adverse effects. The information that needs to be included in an AEE and the proposed projects are outlined in the RMA, or district/regional plans. The local authorities can reject the application, and return it to the applicants within ten working days after the application was first registered if the application is incomplete. The public consultation process is not compulsory in New Zealand, but applicants can still get advice, and consult the local authorities to ensure the application process runs smoothly, and to help identify potential effects that need to be addressed (including effects on other people). In fact, by engaging in consultation or a preapplication meeting, the possibility of the application being completed and accepted for processing by the local authorities will increase.

\section{Stage Two: The local authorities consider the application}

A resource management committee will check the application for completeness. This is to make sure that the application fee, and all the required information is provided at this stage. Then, the local authorities will determine whether the application is publicly notified (to notify the general public), limited notified (to notify only affected parties), or non-notified, to give the public the opportunity to submit or object. The local authorities will decide on whether to inform the application according to:

- the scale and significance of any adverse environmental effects associated with the application;

- whether the application has obtained the written approval of any affected persons; and

- what any relevant national environmental standard and plan requires.

Then a hearing may be held if the general public or the affected parties wish to be heard. The authorities will conduct the hearing. However, the local authorities may arrange a pre-hearing meeting to clarify or resolve issues, which eliminates the need to proceed to a hearing if all the issues of concern can be addressed.

\section{Stage Three: The decision}

The authorities will consider and decide as to whether to grant or refuse the resource consent. The public and limited notified parties who lodged a submission/objection to the application will be informed of the decision. The approved application will likely be subject to certain conditions. If the applicants are not satisfied with the decision or the conditions, they can appeal to the Environment Court, which needs to be done within 15 working days of receiving the decision. 
Marzukhi, M.A., Omar, D., Arshad, A.F., Oliver L.H.L.,, Yusup,M., \& Jaafar, A

One Stop Centre (OSC): Lessons on Best Practices in Planning System Delivery

Furthermore, New Zealand uses MultiProof - an online system to submit building plans that are similar in design many times. According to the Ministry of Business, Innovation and Employability (2016), MultiProof is beneficial for those who:

- build, or intend to build a number of similar designs;

- use standard construction details for a range of similar buildings;

- want to offer customers a lower-cost option;

- want to save time when applying for a building consent;

- need consistency when applying for building consents to different Building Consent Authorities (BCAs);

- want to assure customers that the design will gain building consent; and

- can build the approved design at least 10 times in a two-year period.

The urban planning in New Zealand is an essential contributor to its economic growth, and management of environmental effects. In fact, the ways in which the planning system is processed and delivered can be used as a guide for the delivery mechanism of real estate development in the Malaysian context.

\section{FINDINGS}

Malaysia has adopted a hierarchical planning system, whereby the federal government formulates policies, but planning and implementation responsibilities rest with the state and local governments. Local governments must refer to the development plans, and consider the public's rights in their decision-making processes, including whether to approve or disapprove land development activities. Indeed, planning practice has a role in contributing, often directly, to the country's needs and aspirations, particularly in the decisionmaking process (Porter et al., 2013). In this sense, the local authorities are facing greater challenges due to the increasing urbanisation of the country (Ministry of Housing \& Local Government, 2008).

The challenges are similar in Singapore and New Zealand, where these countries are compounded by rapid population growth due to urbanisation. Therefore, an effective and improved planning system delivery is critical in managing and responding to this pace of urbanisation. Malaysia is currently at a low ranking (24 $4^{\text {th }}$ place) compared to New Zealand $\left(1^{\text {st }}\right)$, and Singapore $\left(2^{\text {nd }}\right)$, as reported by the 2018 World Bank's annual report of Ease of Doing Business Ranking (The World Bank, 2018). This shows that there is still a long way to go for the improvement of the Malaysian planning system delivery. As such, it is important to see what is occurring in actual practice, particularly in the plans and processes that are in place in New Zealand and Singapore in managing their planning systems.

In Singapore, the plans (Concept and Master Plans) and implementation agency (URA) play a significant role in coordinating the technical departments 
PLANNING MALAYSIA

Journal of the Malaysia Institute of Planners (2019)

to ensure that the planning system delivery follows the statutory Master Plan. On the other hand, in New Zealand, the planning delivery system is underpinned by the Resource Management Act 1991. The Act requires local authorities to create plans (regional or district plans) to manage the environment, and the matters that involve resource consent application.

In Malaysia, one of the issues in planning application is the delays. Sometimes, the delays are caused by the OSC procedure itself because it involves too many officers. At the same time, the Professional Submitting Person (PSP) have also submitted application with inadequate documents that ends up dragging the application further into the delay. The delay is also caused by the OSC Department counter since the counter runs short on manpower and expertise even though the current officers at the OSC Department are capable in terms of skills and knowledge. But because of lacking in manpower, the OSC Counter is incapable of conducting most technical requirements like fee calculations, preconsultations, and technical discussions.

According to the World Bank (2018), the pre-consultation process is crucial in dealing with development/construction application. Although preconsultation is not compulsory in New Zealand, it is advisable for applicants to get advice, and consult the local authorities before the application of resource consent. Hence, through the pre-consultation process, the OSC will be able to answer questions from the applicants. To be able to do that, the OSC Department must be more closely involved in the development matters, rather than merely receiving and distributing the application. The OSC Department must start improving their role by deploying capable and knowledgeable officers. By having competent officers, any department, not just the OSC Department, may be able to begin mentoring new officers to help them learn a lot faster. Furthermore, the Professional Submitting Person (PSP) must be informed of the time limitation, and expected timeframe of every process. For instance, the local authority (e.g. Subang Jaya Municipal Council) does not specify in the B2 Form about the 2-day timeframe, the 7-day timeframe, the 14-day timeframe, and the 30-day timeframe, and also the timeframe needed for the PSPs to return their amended plans. In contrast, in New Zealand, its delivery system practices a clear decision timeline (statutory clock) for planning applications (Palmer, 2017).

Currently, the OSC Procedures is considered as a 'one-size-fits-all' procedure as all types of developments (housing, commercial, industrial) are processed through the same procedure. Objective-based approval will help speed up approval by identifying the application by the development type. All the technical agencies involved with development (both internal and external technical agencies) must understand the OSC procedures to help reduce any possible delay in the process. This is especially important for the external technical agencies because they deal with numerous local authorities. The PSP, or the consultant, is key to every successful application. If they do not have an 
Marzukhi, M.A., Omar, D., Arshad, A.F., Oliver L.H.L.,, Yusup,M., \& Jaafar, A

One Stop Centre (OSC): Lessons on Best Practices in Planning System Delivery

understanding of the development guidelines and regulations, one should expect instant failure. To avoid that, every PSP must be well-prepared for any submission of real estate development applications.

\section{CONCLUSION}

There is always a need for constant reform of physical development regulations, which enables technological changes to ensure better physical development control and enforcement as in Singapore (CORENET) and New Zealand (MultiProof). Perhaps, Malaysia should consider this type of system for applications that have a specific set of plans, and certain standard specifications in its planning system. Probably, every local authority should improve their server size (for data storage) accordingly. This will enable the local authority to explore new ways to improve their services, and assist the public. One example is the mailing system. With an online mailing system, any PSP might be able to receive plan reviews with a click of a button (or from a simple SMS). Although there are some similarities between the planning system delivery in Malaysia, and Singapore and New Zealand, yet, there is still a lot Malaysia can learn from both countries to rationalize the success of the property development sector, mainly through its policies and planning practices.

\section{ACKNOWLEDGEMENTS}

The authors would like to thank the National Institute of Valuation (INSPEN) for supporting the study through the NAPREC Grant (100-IRMI/GOV16/6/2(011/2018), Universiti Teknologi MARA, and all the government departments, organisations, and individuals who have contributed to this study.

\section{REFERENCES}

Abdullah, A. A., Harun, Z., \& Rahman, H. A. (2011). Planning process of development project in the Malaysian context: A crucial brief overview. International Journal of Applied Science and Technology, 1(2), 74-81.

Ahmad, I., Ahmad, F., \& Arbi, E. (2011). One Stop Centre as a boon to property development approval process. A case study: City Hall of Kuala Lumpur. Retrieved from http://mjs.um.edu.my/index.php/jdbe/article/download/5308/3101

Fyers, A., \& Flahive, B. (2017). Fast check: New Zealand has the fastest growing population in $O E C D$. Retrieved from http://i.stuff.co.nz.

Hernando, D. S. (2000). The mystery of capital: why capitalism triumphs in the west and fails everywhere else. New York: Basic Books.

Kerzner, H. (2009). Project management: A system approach to planning, scheduling, and controlling (10th ed.). New York: Van Nostrand.

Kincaid, D. (2003) Adapting buildings for changing uses, guidelines for change of use refurbishment. London: Spon Press.

Maidin, A. J. (2012). Malaysian Town and Country Planning: Law and Procedure. Malaysia: CLJ Publication. 
McKim, R., Tarek, H., \& Attalla, M. (2000). Project performance control in reconstruction project. Journal of Construction Engineering and Management, 126(2), 137-141.

Ministry for the Environment NZ (n.d.). Retrieved from http://www.mfe.govt.nz/

Ministry of Business, Innovation and Employability (2016). MultiProof. Retrieved from https://www.building.govt.nz/

Ministry of Housing and Local Government, Malaysia (2008). Upgrading of the procedure on the delivery system and development plan process and the implementation of the One Stop Centre (2nd ed.). Kuala Lumpur: Author.

Mitropoulos, P., \& Howell, G. A. (2002). Renovation projects: Design process problems and improvement mechanisms. Journal of Management in Engineering, 18(4), $179-185$.

Moullier, T. (2009). Reforming building permits: Why is it important and what can IFC really do? Washington, DC.: International Finance Corporation.

Nguyen, L. D., Ogunlana, S. O., \& Lan, D. T. X. (2004). A study on project success factors in large construction projects in Vietnam. Engineering, Construction and Architectural Management, 11 (6), 404-413.

Omar, D., \& Leh, O. L. L. (2009). Malaysian development planning system: Kuala Lumpur Structure Plan and public participation. Asian Social Science, 5(3), 3036.

Palmer, K. (2017). Project: Legal issues in the New Zealand planning system. Retrieved from https://www.productivity.govt.nz

PEMUDAH (2010, October). Seminar on the First Steps of Successful Reform in Doing Business. October 5-6, 2010, Taipei, Chinese Taipei.

Porter, L., Martí-Costa, M., Torvà, M. D., Cohen-Bar, E., Ronel, A., Rogers, D., \& Gibson, C. (2013). Finding hope in unpromising times: Stories of progressive planning alternatives for a world in crisis/Neoliberal planning is not the only way: Mapping. Planning Theory \& Practice, 14(4), 529-529.

Rashid, A. A. (2012). The role of urban governance to enhance Kuala Lumpur CityRegion development. Global Journal of Human Social Science Arts \& Humanities, 12(12), 16-24.

Singapore Department of Statistics (2017). Retrieved from http://www.singstat.gov.sg.

StatsNZ (n.d.). Retrived from https://www.stats.govt.nz

Town and Country Planning Act 1976 (2009) (Malaysia)

United Nations (n.d.). Sustainable development goals. Retrieved from http://www.un.org/sustainabledevelopment/sustainable-development-goals/

Urban Redeelopment Authority (n.d.). Retrieved from https://www.ura.gov.sg

Watson, V. (2013). Planning and the 'stubborn realities' of global south-east cities: Some emerging ideas. Planning Theory, 12(1), 81-100.

The World Bank (2018). Doing Business 2018. Reforming to Create Jobs. A World Bank Group Flagship Report, Washington.

Yuen, B. (2009). Guiding Spatial Changes: Singapore Urban Planning. In Lall, S.V. et al. Urban Land Markets. Improving Land Management for Successful Urbanization. Springer: USA

Received: $28^{\text {th }}$ October 2018. Accepted: $1^{\text {st }}$ March 2019 